\title{
PENGARUH KEMATANGAN GURU, LINGKUNGAN KERJA DAN KEPEMIMPINAN KEPALA MADRASAH TERHADAP KINERJA GURU PADA MADRASAH ALIYAH NEGERI KABUPATEN BATU BARA
}

\author{
${ }^{1}$ Syahri Mauliddin, ${ }^{2}$ Khairunnisya, ${ }^{3}$ Muhammad Sya'i, ${ }^{4}$ M. Syafi'i,. ${ }^{5}$ Ayu Roza Fiitri \\ ${ }_{1,2,3,4,5}$ Universitas Islam Sumatera Utara \\ ${ }^{1}$ syahri.mauliddin@gmail.com, ${ }^{2}$ khairnnisya.mm@gmail.com, ${ }_{5}^{3}$ mhd.syai@gmail.com, ${ }_{5}^{4}$ mhd.syafii@ gmail.com, \\ 5ayuroza.fitri@gmail.com
}

\begin{abstract}
Problem of this study is how influence of teacher's maturity on teacher's performance. How influence of job environment on teacher's performance. How influence of head leadership of madrasah on teacher's performance. How influence teacher's maturity, job environment and head leadership of madrasah on teacher's performance.

The purpose of this study to determine and analyze the effect of teacher's maturity on teacher's performance. Determine and analyze the effect of job environment on teacher's performance. Determine and analyze the effect of head leadership of madrasah on teacher's performance. Determine and analyze the effect of teacher's maturity, job environment and head leadership of madrasah on teacher's performance. Sample in the study is 52 teacher's. Data analysis techniques used in this study is descriptive analyze and multiple linear regression analysis. The results of the study indicate teacher's maturity variable has a positive and significant effect on teacher's performance. Teacher's job environment variable has a positive and significant effect on teacher's performance. Head leadership of madrasah variable has a positive and significant effect on teacher's performance. The teacher's maturity, job environment and head leadership of madrasah variable has a positive and significant effect on teacher's performance.
\end{abstract}

Keywords : Maturity, Job environment, Leadership, Performance.

ABSTRAK : Rumusan masalah dalam penelitian ini adalah bagaimana pengaruh kematangan guru terhadap kinerja guru. Bagaimana pengaruh lingkungan kerja terhadap kinerja guru. Bagaimana pengaruh kepemimpinan kepala madrasah terhadap kinerja guru. Bagaimana pengaruh kematangan guru, lingkungan kerja dan kepemimpinan kepala madrasah terhadap kinerja guru. Tujuan penelitian ini adalah untuk mengetahui dan menganalisis pengaruh kematangan guru terhadap kinerja guru. Untuk mengetahui dan menganalisis pengaruh lingkungan kerja terhadap kinerja guru. Untuk mengetahui dan menganalisis pengaruh kepemimpinan kepala madrasah terhadap kinerja guru. Untuk mengetahui dan menganalisis pengaruh kematangan guru, lingkungan kerja dan kepemimpinan kepala madrasah terhadap kinerja guru. Sampel dalam penelitian ini berjumlah 52 orang guru. Teknik analisis data yang digunakan dalam penelitian ini adalah analisis deskriptif dan analisis regresi linier berganda. Hasil penelitian ini menjelaskan bahwa variabel kematangan guru berpengaruh positif dan signifikan terhadap kinerja guru. Variabel lingkungan kerja berpengaruh positif dan signifikan terhadap kinerja guru. Variabel kepemimpinan kepala madrasah berpengaruh positif dan signifikan terhadap kinerja guru. Variabel kematangan guru, lingkungan kerja dan kepemimpinan kepala madrasah berpengaruh positif dan signifikan terhadap kinerja guru.

Kata kunci : Kematangan, Lingkungan kerja, Kepemimpinan, Kinerja

\section{Pendahuluan}

Madrasah adalah lembaga yang bersifat kompleks dan unik. Bersifat kompleks karena madrasah sebagai organisasi yang didalamnya terdapat berbagai dimensi yang satu sama lain saling berkaitan dan saling menentukan. Sedang 
bersifat unik, menunjukkan bahwa madrasah sebagai organisasi memiliki ciri-ciri tertentu yang tidak dimiliki oleh organisasi-organisasi lain, yaitu ciri-ciri yang menempatkan madrasah memiliki karakter sendiri, dimana terjadi proses belajar mengajar tempat terselenggarakannya pembudayaan kehidupan umat manusia.

Kepala Madrasah merupakan personel sekolah yang bertanggung jawab terhadap seluruh kegiatan-kegiatan sekolah. Ia mempunyai wewenang dan tanggung jawab penuh untuk menyelenggarakan seluruh kegiatan pendidikan dalam lingkungan sekolah yang dipimpinnya. Kepala Madrasah selain bertanggung jawab atas kelancaran jalannya sekolah secara teknis akademis juga bertanggung jawab atas segala kegiatan, keadaan lingkungan madrasah dengan kondisi dan situasinya serta hubungan dengan masyarakat sekitar, Daryanto (2010:80).

Guru Madrasah Aliyah Negeri Kabupaten Batu Bara merupakan salah satu sumber daya sekolah yang mempunyai nilai prakarsa dan memiliki peran penting dalam pemberdayaan sumber daya lainnya dalam sekolah. Sistem pengelolaan Sumber Daya Manusia (SDM) yang tepat merupakan kunci keberhasilan Madrasah Aliyah Negeri Kabupaten Batu Bara untuk mencapai tujuannya. Oleh karena itu, agar tujuan dan sasarannya dapat dicapai, perlu adanya perhatian yang lebih dari pimpinan terhadap upaya-upaya dalam meningkatkan kinerja guru.

Daryanto (2010:43), kinerja guru merupakan hasil proses yang kompleks, baik berasal dari diri pribadi guru (internal factor) maupun upaya strategis dari organisasi. Kinerja adalah hasil akhir atau kemampuan kerja seseorang atau kelompok orang atas suatu pekerjaan pada waktu tetentu. Bentuk kinerja itu dapat berupa akhir atau produk barang dan jasa, bentuk perilaku, kecakapan, kompetensi, sarana dan sebagainya. Depdiknas (2016: 4) mengartikan kinerja dengan prestasi kerja atau unjuk kerja. Kinerja adalah suatu bentuk hasil kerja atau hasil usaha berupa tampilan fisik, maupun gagasan.

Dari pendapat para ahli tersebut di atas dan berlandaskan pada studi empirikal peneliti mencoba melihat permasalahan tentang kinerja guru Madrasah Aliyah Negeri Kabupaten Batu Bara yang terlihat masih belum optimal. Hal ini disebabkan oleh kematangan guru. Menurut pendapat Suryana (2014:88) kematangan adalah kemampuan individu untuk dapat mengontrol dan mengendalikan diri terhadap pekerjaan yang menjadi tanggung jawabnya. Kematangan mempunyai ciri-ciri penerimaan diri, baik individu yang memiliki kematangan akan dapat menerima kondisi fisik maupun psikisnya, baik secara pribadi maupun secara sosial, dan kemampuan dalam mengontrol dorongan yang muncul dalam diri individu untuk melakukan sesuatu yang bertentangan dengan nilai-nilai yang berlaku akan dapat dikendalikan dan diorganisasikan ke arah yang baik. Fenomena tentang kematangan guru Madrasah Aliyah Negeri Kabupaten Batu Bara diantaranya guru kurang memahami visi, misi, sasaran dan tujuan madrasah, sebagian guru kurang bersikap sabar jika ada masalah dalam proses pembelajaran.

Variabel kedua yang mempengaruhi kinerja guru Madrasah Aliyah Negeri Kabupaten Batu Bara adalah lingkungan kerja. Hasil penelitian yang dilakukan oleh Tri Widari (2016) menunjukkan bahwa lingkungan kerja berpengaruh signifikan terhadap kinerja, begitu juga hasil penelitian dari Dewa (2015) menyatakan bahwa lingkungan kerja berpengaruh terhadap kinerja. Berdasarkan temuan penelitian tersebut maka penelitian ini bertujuan untuk menganalisis dan menguji kembali pengaruh lingkungan kerja terhadap kinerja guru Madrasah Aliyah Negeri Kabupaten Batu Bara. Berdasarkan survei awal fenomena tentang lingkungan kerja diantaranya penerangan pada ruang kerja dan ruang kelas masih kurang terang dan kondisi ruang kelas tertata kurang rapi.

Variabel ketiga yang mempengaruhi kinerja guru Madrasah Aliyah Negeri Kabupaten Batu Bara adalah kepemimpinan. Penelitian dari Fauzi (2013) menyatakan bahwa faktor kepemimpinan berpengaruh terhadap kinerja. Hal ini sesuai dengan pengertian kepemimpinan dari Siagian (2013:124) bahwa kepemimpinan adalah kemampuan dan keterampilan seseorang yang menduduki jabatan sebagai pemimpin satuan kerja untuk mempengaruhi prilaku orang lain terutama bawahannya untuk berfikir dan untuk bertindak sedemikian rupa sehingga melalui prilaku yang positif ia memberikan sumbangsih yang nyata dalam pencapaian tujuan organisasi. Untuk mencapai tujuan bersama, guru yang ada di Madrasah Aliyah Negeri Kabupaten Batu Bara perlu membina kebersamaan dengan mengikuti pengendalian dari pemimpinnya. Dengan pengendalian tersebut, perbedaan keinginan, 
kehendak, kemauan, perasaan, kebutuhan dan lain-lain dipertemukan untuk digerakkan kearah yang sama. Dengan demikian berarti perbedaan individual dimanfaatkan untuk mencapai tujuan yang sama sebagai kegiatan kepemimpinan atasan di Madrasah Aliyah Negeri Kabupaten Batu Bara. Kepala Madrasah pada hakikatnya adalah pejabat formal, sebab pengangkatannya melalui suatu proses dan prosedur yang didasarkan atas peraturan yang berlaku. Karena itulah Kepala Madrasah mempunyai tanggung jawab yaitu kepada atasan, kepada bawahan, kepada sesama rekan Kepala Madrasah atau instansi terkait. Berdasarkan pengamatan yang penulis lakukan terhadap 10 orang guru, penulis menemukan bahwa masih ada guru yang merasakan bahwa mereka diperlakukan secara tidak adil (kognitif), guru menunjukkan sikap mengkritisasi segala bentuk kebijakan atasan serta perencanaan kerja dari atasan belum sepenuhnya dapat terserap oleh para guru. Kondisi-kondisi tersebut menggambarkan atau merupakan fenomena terjadinya masalah kepemimpinan di Madrasah Aliyah Negeri Kabupaten Batu Bara.

\subsection{Batasan Masalah}

Agar permasalahan yang dikaji terarah maka permasalahan dibatasi sebagai berikut. Penelitian ini hanya membahas faktor kematangan guru, lingkungan kerja, kepemimpinan kepala madrasah dan kinerja guru Madrasah Aliyah Negeri Kabupaten Batu Bara.

\subsection{Hioptesis}

Hipotesis dalam penelitian ini adalah :

1) Kematangan guru berpengaruh positif dan signifikan terhadap kinerja guru Madrasah Aliyah Negeri Kabupaten Batu Bara.

2) Lingkungan kerja berpengaruh positif dan signifikan terhadap kinerja guru Madrasah Aliyah Negeri Kabupaten Batu Bara

3) Kepemimpinan kepala madrasah berpengaruh positif dan signifikan terhadap kinerja guru Madrasah Aliyah Negeri Kabupaten Batu Bara

4) Kematangan guru, lingkungan kerja dan kepemimpinan kepala madrasah berpengaruh positif dan signifikan terhadap kinerja guru Madrasah Aliyah Negeri Kabupaten Batu Bara.

$$
\text { ii. }
$$

\subsection{Tujuan Penelitian}

Tujuan penelitian ini adalah :
1) Untuk mengetahui pengaruh kematangan guru terhadap kinerja guru Kantor Camat Sayurmatinggi Kabupaten Tapanuli Selatan.

2) Untuk mengetahui pengaruh lingkungan kerja terhadap kinerja guru Madrasah Aliyah Negeri Kabupaten Batu Bara.

3) Untuk mengetahui pengaruh kepemimpinan kepala madrasah terhadap kinerja guru Madrasah Aliyah Negeri Kabupaten Batu Bara

4) Untuk mengetahui pengaruh kematangan guru, lingkungan kerja, dan kepemimpinan kepala madrasah terhadap kinerja guru Madrasah Aliyah Negeri Kabupaten Batu Bara.

\section{Metode Penelitian}

\subsection{Populasi}

Populasi merupakan subjek penelitian dimana individu yang akan dikenai perilaku atau dapat dikatakan sebagai keseluruhan objek penelitian yang akan diteliti. Maka yang menjadi populasi dalam penelitian ini adalah seluruh guru Madrasah Aliyah Negeri Kabupaten Batu Bara yang berjumlah 52 orang, dimana Kepala Madrasah dan peneliti tidak disertakan sebagai populasi.

Tabel 1. Kerangka populasi guru

\begin{tabular}{|c|l|c|}
\hline No & Keterangan & Jumlah (Orang) \\
\hline 1 & Guru tetap/PNS & 32 \\
\hline 2 & Guru honorer & 20 \\
\hline \multicolumn{2}{|c|}{ Jumlah } & 52 \\
\hline & $\begin{array}{l}\text { Sumber : Madrasah Aliyah Negeri Kabupaten Batu Bara, } \\
2020\end{array}$
\end{tabular}

\subsection{Sampel}

Dengan menggunakan teknik penarikan sampel yaitu total sampling atau metode sensus, maka sampel dalam penelitian ini berjumlah 52 orang guru Madrasah Aliyah Negeri Kabupaten Batu Bara.

Tabel 2. Kerangka sampel guru

\begin{tabular}{|c|c|c|}
\hline No & Keterangan & Jumlah (Orang) \\
\hline 1 & Guru tetap/PNS & 32 \\
\hline 2 & Guru honorer & 20 \\
\hline \multicolumn{2}{|c|}{ Jumlah } & 52 \\
\hline
\end{tabular}

Sumber : Madrasah Aliyah Negeri Kabupaten Batu Bara, 2020

\subsection{Uji Normalitas}

Menurut Sugiyono (2014:144) pengertian dari uji normalitas adalah untuk menguji apakah nilai residual yang dihasilkan dari regresi terdistribusi secara normal atau tidak. Model regresi yang baik adalah yang memiliki nilai 
residual yang terdistribusi normal. Untuk mengetahui bentuk distribusi data, bisa dilakukan dengan grafik distribusi dan analisis statistik. Pengujian dengan distribusi dilakukan dengan melihat grafik histogram yang membandingkan antara dua observasi dengan distribusi yang mendekati distribusi normal. Distribusi normal akan membentuk satu garis lurus diagonal dan ploating data residual akan dibandingkan dengan garis diagonal. Jika distribusi atau residual normal, maka garis yang menggambarkan data yang sesungguhnya akan mengikuti garis diagonalnya. Uji normalitas dengan grafik dapat dilakukan dengan program SPSS dengan analisis grafik Normal Probability Plot

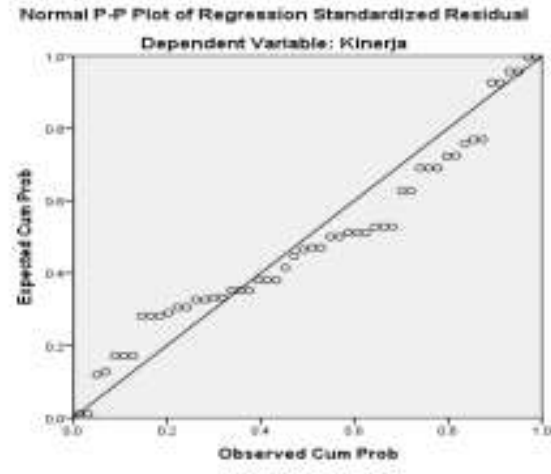

Gambar 1. Uji normalitas data

Berdasarkan gambar 5.1, diatas terlihat titik-titik dari ploating data residual berada di garis diagonal, hal ini dapat disimpulkan data yang diuji berdistribusi normal.

\subsection{Uji Multikolinieritas}

Salah satu asumsi dari model regresi linier bahwa tidak terjadi korelasi yang signifikan antara variabel bebasnya. Untuk menguji hal tersebut maka diperlukan suatu uji yang disebut uji multikolinieritas. Menurut Sugiyono (2014:151) pengertian multikolinieritas adalah keadaan di mana pada model regresi ditemukan adanya korelasi yang sempurna atau mendekati sempurna antar variabel independen. Pada regresi yang baik seharusnya tidak terjadi korelasi yang sempurna atau mendekati sempurna diantara variabel bebas. Uji multikolinieritas adalah untuk melihat ada atau tidaknya korelasi yang tinggi antara variabelvariabel bebasnya, maka hubungan antara variabel bebas terhadap variabel terikatnya menjadi terganggu. Jika terdapat korelasi yang kuat dimana sesama variabel independen maka konsekuensinya adalah : a. Koefisien-koefisien regresi menjadi tidak dapat ditaksir

b. Nilai standar error setiap koefisien regresi menjadi tidak terhingga.

Dengan demikian, semakin besar korelasi diantara sesama variabel independen maka tingkat kesalahan dari koefisien regresi semakin besar yang dapat mengakibatkan standar error semakin besar pula. Cara yang digunakan untuk mendeteksi ada tidaknya multikolinieritas adalah dengan melihat besarnya nilai Variance Inflation Factor (VIF). Jika VIF dibawah 10 dan Tolerance Value diatas 0,1 maka tidak terjadi multikolinieritas.

Tabel 3. Uji multikolinieritas

\begin{tabular}{|l|c|c|}
\hline \multirow{2}{*}{ Variabel } & \multicolumn{2}{|c|}{ Collinearity Statistics } \\
\cline { 2 - 3 } & Tolerance & \multicolumn{1}{c|}{ VIF } \\
\hline Kematangan guru & 0.773 & 1.293 \\
\hline Lingkungan kerja & 0.887 & 1.127 \\
\hline $\begin{array}{l}\text { Kepemimpinan } \\
\text { kepala madrasah }\end{array}$ & 0.793 & 1.261 \\
\hline $\begin{array}{l}\text { a Dependent Variable : Kinerja } \\
\text { Sumber : Hasil pengolahan data, 2020 }\end{array}$
\end{tabular}

Berdasarkan Tabel 3 diatas diperoleh nilai Tolerance Value diatas 0.1 yaitu $0.773,0.887$, 0.793; hal ini menunjukan adanya korelasi yang cukup tinggi/kuat antara sesama variabel bebas dan nilai Variance Inflantion Factorrs (VIF) sebesar 1.293, 1.127, 1.261, dimana nilai VIF dari ketiga varibel bebas lebih kecil dari 10 dan dapat disimpulkan tidak terdapat multikolinieritas diantara ketiga variabel bebas yang diuji dalam penelitian ini.

\subsection{Uji Autokorelasi}

Uji autokorelasi merupakan pengujian dimana variabel dependen tidak berkorelasi dengan nilai variabel itu sendiri, baik nilai periode sebelumnya maupun nilai periode sesudahnya. Menurut Sugiyono (2014:172) pengertian dari autokorelasi adalah keadaan di mana pada model regresi ada korelasi antara residual pada periode tertentu $t$ dengan residual pada periode sebelumnya ( $\mathrm{t}-1)$, model regresi yang baik adalah yang tidak terdapat masalah autokorelasi. Metode pengujian menggunakan uji Durbin-Watson (DW-test). Salah satu ukuran dalam menentukan ada tidaknya masalah autokorelasi dengan uji Durbin-Watson (DW) dengan ketentuan sebagai berikut :

$1.65<\mathrm{DW}<2.35$ tidak terjadi autokorelasi

1.21. $<\mathrm{DW}<1.65$ atau $2.35<\mathrm{DW}<2.79$ tidak dapat disimpulkan.

DW $<1.21$ atau DW $>2.79$ terjadi autokorelasi. 
Tabel 4. Uji Autokorelasi

\begin{tabular}{|c|c|c|c|c|c|c|}
\hline \multirow[b]{2}{*}{ Model } & \multicolumn{5}{|c|}{ Change Statistics } & \multirow{2}{*}{$\begin{array}{l}\text { Durbin- } \\
\text { Watson }\end{array}$} \\
\hline & $\begin{array}{c}\text { R Square } \\
\text { Change }\end{array}$ & F Change & df1 & $\mathrm{df} 2$ & $\begin{array}{c}\text { Sig. F } \\
\text { Change }\end{array}$ & \\
\hline 1 & .708 & 63.155 & 3 & 78 & .000 & 2.105 \\
\hline
\end{tabular}

Berdasarkan Tabel 4 di atas diperoleh nilai Durbin-Watson (DW) sebesar 2.105, nilai ini berada pada kisaran $1.65<\mathrm{DW}<2.35$, maka dapat disimpulkan bahwa tidak terjadi autokorelasi pada model regresi yang diuji dalam penelitian ini.

\subsection{Uji Heteroskedastisitas}

Uji heteroskedastisitas dapat dilakukan dengan menggunakan grafik scatterplot antara nilai variabel terikat (ZSPRED) dengan residualnya (SRESID), dimana sumbu $X$ adalah yang diprediksi dan sumbu $\mathrm{Y}$ adalah residual. Dasar pengambilan keputusan yang dapat diambil adalah sebagai berikut :

a. Jika pola tertentu seperti titik-titik yang ada membentuk suatu pola yang teratur (bergelombang, melebar kemudian menyempit) maka telah terjadi heteroskedastisitas.

b. Jika tidak ada yang jelas serta titik-titik menyebar diatas dan dibawah angka nol pada sumbu Y maka tidak terjadi heteroskedastisitas

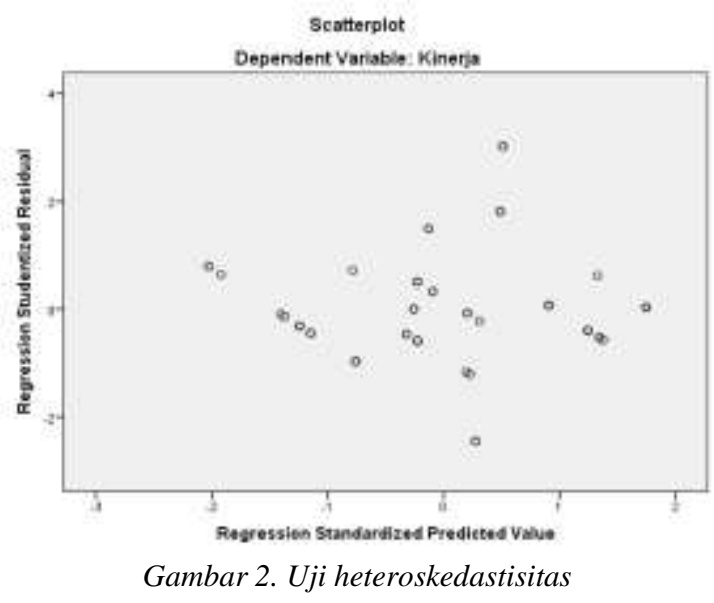

Berdasarkan gambar 2, diatas, menunjukkan titik-titik yang menyebar, sehingga dapat disimpulkan tidak terjadi heteroskedastisitas di data penelitian ini.

\section{Evaluasi Data}

Dalam evaluasi data ini peneliti akan melihat model persamaan regresi linier berganda dan akan menguji kebenaran hipotesis baik itu secara partial atau sendiri-sendiri, maupun secara simultan atau bersama-sama, dan untuk memudahkan peneliti dalam pengolahan data, maka digunakan Program Statistical Product and Service Solutions versi 22.00 .

\subsection{Analisis Regresi Linier Berganda.}

Analisis regresi linier berganda dalam penelitian ini dapat dilihat dari persamaan regresinya, dan dari hasil pengolahan data diperoleh hasil berikut ini :

Tabel 5. Analisis regresi linier berganda

\begin{tabular}{|l|r|r|r|r|r|}
\hline \multirow{2}{*}{ Model } & \multicolumn{2}{|c|}{$\begin{array}{c}\text { Unstandardized } \\
\text { Coefficients }\end{array}$} & $\begin{array}{c}\text { Standardized } \\
\text { Coefficients } \\
\text { Beta }\end{array}$ & $\mathrm{t}$ & \multirow{2}{*}{ Sig. } \\
\cline { 2 - 3 } & \multicolumn{1}{|c|}{$\mathrm{B}$} & Std. Error & & \\
\hline (Constant) & 5.820 & 4.431 & & 1.314 & .195 \\
\hline Kematangan guru & .259 & .099 & .255 & 2.632 & .011 \\
\hline Lingkungan kerja & .180 & .064 & .210 & 2.261 & .013 \\
\hline $\begin{array}{l}\text { Kepemimpinan } \\
\text { kepala madrasah }\end{array}$ & .518 & .081 & .622 & 6.364 & .000 \\
\hline
\end{tabular}

Sumber : Hasil pengolahan data, 2020 
Berdasarkan Tabel 5, diatas dapat dibuat persamaan regresi dalam penelitian ini sebagai berikut :

$$
\mathrm{Y}=5.820+0.259 \mathrm{X}_{1}+0.180 \mathrm{X}_{2}+0.518 \mathrm{X}_{3}
$$

Dari persamaan regresi linier berganda di atas dapat dijelaskan :

1) Nilai kinerja guru di Madrasah Aliyah Negeri Kabupaten Batu Bara sebesar 5.820, dengan ketentuan nilai dari variabel bebas $\left(\mathrm{X}_{1}, \mathrm{X}_{2}\right.$, dan $\left.\mathrm{X}_{3}\right)$ diabaikan.

2) Nilai koefisien regresi $X_{1}$ (kematangan guru) mempunyai nilai positif yaitu 0.259 , hal ini menunjukkan bahwa variabel kematangan guru mempunyai pengaruh positif terhadap kinerja guru di Madrasah Aliyah Negeri Kabupaten Batu Bara.

3) Nilai koefisien regresi $X_{2}$ (lingkungan kerja) mempunyai nilai positif yaitu 0.180 , hal ini menunjukkan bahwa variabel lingkungan kerja mempunyai pengaruh positif terhadap kinerja guru di Madrasah Aliyah Negeri Kabupaten Batu Bara.

4) Nilai koefisien regresi $X_{3}$ (kepemimpinan kepala madrasah) mempunyai nilai positif yaitu 0.518, hal ini menunjukkan bahwa variabel kepemimpinan kepala madrasah mempunyai pengaruh positif terhadap kinerja guru di Madrasah Aliyah Negeri Kabupaten Batu Bara.

\subsection{Pengaruh Kematangan Guru Terhadap Kinerja Guru Di Madrasah Aliyah Negeri Kabupaten Batu Bara.}

Untuk mengetahui pengaruh kematangan guru terhadap kinerja guru di Madrasah Aliyah Negeri Kabupaten Batu Bara. digunakan uji-t, sedangkan untuk melihat besarnya pengaruh digunakan nilai Beta atau Standardized Coefficient Beta.

Tabel. 6. Pengaruh kematangan guru terhadap kinerja

\begin{tabular}{|l|r|r|r|r|r|}
\hline \multirow{2}{*}{ Model } & \multicolumn{2}{|c|}{$\begin{array}{c}\text { Unstandardized } \\
\text { Coefficients }\end{array}$} & $\begin{array}{c}\text { Standardized } \\
\text { Coefficients } \\
\text { Beta }\end{array}$ & $\mathrm{t}$ & \multirow{2}{*}{ Sig. } \\
\cline { 2 - 3 } & \multicolumn{1}{|c|}{$\mathrm{B}$} & \multicolumn{1}{|c|}{ Std. Error } & & \\
\hline (Constant) & 5.820 & 4.431 & & 1.314 & .195 \\
\hline Kematangan guru & .259 & .099 & .255 & 2.632 & .011 \\
\hline
\end{tabular}

a. Dependent Variable : Kinerja

Sumber : Hasil pengolahan data, 2020

Dari Tabel 6 diatas diperoleh nilai $\mathrm{t}_{\text {hitung }}$ sebesar 2.632. Penelitian ini menggunakan taraf signifikansi $(\alpha: 0.05)$ dan Derajat Kebebasan (DK) dengan ketentuan DK $=\mathrm{n}-2$, atau $52-2$ $=50$.

Dengan ketentuan tersebut, diperoleh nilai $t_{\text {tabel }}$ sebesar 2.009. Dengan kriteria hipotesis sebagai berikut :

Jika nilai $t_{\text {hitung }}>t_{\text {tabel}}$, maka hipotesis penelitian diterima.

Jika nilai $t_{\text {hitung }}<t_{\text {tabel }}$, maka hipotesis penelitian ditolak.

Dari hasil pengolahan data diperoleh nilai $t_{\text {hitung }}>t_{\text {tabel }}(2.632>2.009)$ dan nilai signifikasi lebih kecil dari nilai $\alpha: 0.05$ yaitu $0.011<0.05$, sehingga hipotesis yang diajukan dalam penelitian ini diterima. Artinya variabel kematangan guru secara partial berpengaruh positif dan signifikan terhadap kinerja guru di Madrasah Aliyah Negeri Kabupaten Batu Bara. Besarnya pengaruh variabel kematangan guru terhadap kinerja guru di Madrasah Aliyah
Negeri Kabupaten Batu Bara sebesar 0.255 atau $25.50 \%$. Hasil penelitian ini sejalan dengan hasil penelitian Rohmat Hasan (2015) yang mana kesemuanya menyatakan kematangan atau masa kerja berpengaruh positif dan signifikan terhadap kinerja. Deskripsi dari hasil penelitian ini adalah jika tingkat kematangan guru sudah baik maka akan berdampak pada peningkatan kinerja guru, begitu juga sebalikny jika tingkat kematangan guru belum baik, maka akan berdampak pada penurunan kinerja gru di Madrasah Aliyah Negeri Kabupaten Batu Bara.

\subsection{Pengaruh Lingkungan Kerja Terhadap Kinerja Guru Di Madrasah Aliyah Negeri Kabupaten Batu Bara. \\ Untuk mengetahui pengaruh lingkungan} kerja terhadap kinerja guru di Madrasah Aliyah Negeri Kabupaten Batu Bara. digunakan uji-t, sedangkan untuk melihat besarnya pengaruh digunakan nilai Beta atau Standardized Coefficient Beta. 
Tabel. 7, Pengaruh lingkungan kerja terhadap kinerja

\begin{tabular}{|l|r|r|r|r|r|}
\hline \multirow{2}{*}{ Model } & \multicolumn{2}{|c|}{$\begin{array}{c}\text { Unstandardized } \\
\text { Coefficients }\end{array}$} & $\begin{array}{c}\text { Standardized } \\
\text { Coefficients } \\
\text { Beta }\end{array}$ & $\mathrm{t}$ & \multirow{2}{*}{ Sig. } \\
\cline { 2 - 3 } & \multicolumn{1}{|c|}{$\mathrm{B}$} & \multicolumn{1}{|c|}{ Std. Error } & & & \\
\hline (Constant) & 5.820 & 4.431 & & 1.314 & .195 \\
\hline Lingkungan kerja & .180 & .064 & .210 & 2.261 & .013 \\
\hline
\end{tabular}

a. Dependent Variable : Kinerja

Sumber : Hasil pengolahan data, 2020

Dari Tabel 7 diatas diperoleh nilai $\mathrm{t}_{\text {hitung }}$ sebesar 2.261. Penelitian ini menggunakan taraf signifikansi $(\alpha: 0.05)$ dan Derajat Kebebasan (DK) dengan ketentuan DK $=\mathrm{n}-2$, atau $52-2$ $=50$. Dengan ketentuan tersebut, diperoleh nilai $\mathrm{t}_{\text {tabel }}$ sebesar 2.009. Dengan kriteria hipotesis sebagai berikut :

Jika nilai $t_{\text {hitung }}>t_{\text {tabel}}$, maka hipotesis penelitian diterima.

Jika nilai $t_{\text {hitung }}<t_{\text {tabel}}$, maka hipotesis penelitian ditolak.

Dari hasil pengolahan data diperoleh nilai $t_{\text {hitung }}>t_{\text {tabel }}(2.261>2.009)$ dan nilai signifikasi lebih kecil dari nilai $\alpha: 0.05$ yaitu $0.013<0.05$, sehingga hipotesis yang diajukan dalam penelitian ini diterima. Artinya variabel lingkungan kerja secara partial berpengaruh positif dan signifikan terhadap kinerja guru di Madrasah Aliyah Negeri Kabupaten Batu Bara. Besarnya pengaruh variabel lingkungan kerja terhadap kinerja guru di Madrasah Aliyah Negeri Kabupaten Batu Bara sebesar 0.210 atau $21 \%$. Hasil penelitian ini sejalan dengan hasil penelitian Iskandar, S (2019), Tri Widari (2016) dan Dewa Putu Meles Arta (2015), , yang mana kesemuanya menyatakan lingkungan kerja berpengaruh positif dan signifikan terhadap kinerja. Deskripsi dari hasil penelitian ini adalah jika lingkungan kerja sudah baik maka akan berdampak pada peningkatan kinerja guru, begitu juga sebaliknya jika lingkungan kerja belum baik, maka akan berdampak pada penurunan kinerja guru di Madrasah Aliyah Negeri Kabupaten Batu Bara.

\subsection{Pengaruh Kepemimpinan Kepala Madrasah Terhadap Kinerja Guru Di Madrasah Aliyah Negeri Kabupaten Batu Bara. \\ Untuk mengetahui pengaruh} kepemimpinan kepala madrasah terhadap kinerja guru di Madrasah Aliyah Negeri Kabupaten Batu Bara. digunakan uji-t, sedangkan untuk melihat besarnya pengaruh digunakan nilai Beta atau Standardized Coefficient Beta.

Tabel. 8 Pengaruh kepemimpinan kepala madrasah terhadap kinerja

\begin{tabular}{|l|r|r|r|r|r|}
\hline \multirow{2}{*}{ Model } & \multicolumn{2}{|c|}{$\begin{array}{c}\text { Unstandardized } \\
\text { Coefficients }\end{array}$} & \multirow{2}{*}{$\begin{array}{c}\text { Standardized } \\
\text { Coefficients } \\
\text { Beta }\end{array}$} & $\mathrm{t}$ & \multirow{2}{*}{ Sig. } \\
\cline { 2 - 3 } & \multicolumn{1}{c|}{$\mathrm{B}$} & \multicolumn{1}{|c|}{ Std. Error } & & \\
\hline $\begin{array}{l}\text { (Constant) } \\
\text { Kepemimpinan kepala } \\
\text { madrasah }\end{array}$ & 5.820 & 4.431 & & 1.314 & .195 \\
\hline
\end{tabular}

a. Dependent Variable : Kinerja

Sumber : Hasil pengolahan data, 2020

Dari Tabel 8 diatas diperoleh nilai $t_{\text {hitung }}$ sebesar 6.364. Penelitian ini menggunakan taraf signifikansi $(\alpha: 0.05)$ dan Derajat Kebebasan (DK) dengan ketentuan DK $=\mathrm{n}-2$, atau $52-2$ $=50$. Dengan ketentuan tersebut, diperoleh nilai $t_{\text {tabel }}$ sebesar 2.009. Dengan kriteria hipotesis sebagai berikut :

Jika nilai $t_{\text {hitung }}>t_{\text {tabel}}$, maka hipotesis penelitian diterima.

Jika nilai $t_{\text {hitung }}<t_{\text {tabel}}$, maka hipotesis penelitian ditolak.
Dari hasil pengolahan data diperoleh nilai $t_{\text {hitung }}>t_{\text {tabel }}(6.364>2.009)$ dan nilai signifikasi lebih kecil dari nilai $\alpha: 0.05$ yaitu $0.00<0.05$, sehingga hipotesis yang diajukan dalam penelitian ini diterima. Artinya variabel kepemimpinan kepala madrasah secara partial berpengaruh positif dan signifikan terhadap kinerja guru di Madrasah Aliyah Negeri Kabupaten Batu Bara. Besarnya pengaruh variabel kepemimpinan kepala madrasah terhadap kinerja guru di Madrasah Aliyah Negeri Kabupaten Batu Bara sebesar 0.622 atau 
62.20\%. Hasil penelitian ini sejalan dengan hasil penelitian Fauzi, A (2013), Iskandar, S (2019), dan Rahman, Hasan Taufan (2014), yang mana kesemuanya menyatakan kepemimpinan berpengaruh positif dan signifikan terhadap kinerja. Deskripsi dari hasil penelitian ini adalah jika pimpinan dapat memperhatikan bawahan dalam hal ini guru dengan baik maka akan berdampak pada peningkatan kinerja guru, begitu juga sebaliknya jika pimpinan tidak dapat memperhatikan bawahan dalam hal ini guru dengan baik, maka akan berdampak pada penurunan kinerja guru di Madrasah Aliyah Negeri Kabupaten Batu Bara.

\subsection{Pengaruh Kematangan Guru, Lingkungan Kerja Dan Kepemimpinan Kepala Madrasah Terhadap Kinerja Guru Di Madrasah Aliyah Negeri Kabupaten Batu Bara}

Untuk mengetahui pengaruh kematangan guru, lingkungan kerja dan kepemimpinan kepala madrasah terhadap kinerja guru di Madrasah Aliyah Negeri Kabupaten Batu Bara digunakan uji-F.

Tabel 9. Pengaruh kematangan guru, lingkungan kerja dan kepemimpinan kepala madrasah terhadap kinerja

\begin{tabular}{|l|l|r|r|r|r|c|}
\hline \multirow{2}{*}{ Model } & & $\begin{array}{c}\text { Sum of } \\
\text { Squares }\end{array}$ & \multicolumn{1}{c|}{$\mathrm{df}$} & $\begin{array}{c}\text { Mean } \\
\text { Square }\end{array}$ & \multicolumn{1}{c|}{ F } & \multicolumn{1}{c|}{ Sig. } \\
\hline \multirow{3}{*}{1} & Regression & 310.632 & 3 & 103.544 & 30.044 & $.000^{\mathrm{a}}$ \\
\cline { 2 - 7 } & Residual & 165.426 & 48 & 3.446 & & \\
\cline { 2 - 7 } & Total & 476.058 & 51 & & & \\
\hline
\end{tabular}

Dependent Variable : Kinerja

Sumber : Hasil pengolahan data, 2020

Dari Tabel 9 di atas diperoleh nilai $\mathrm{F}_{\text {hitung }}$ sebesar 30.044. Penelitian ini menggunakan taraf signifikansi $(\alpha: 0.05)$ dan Derajat Kebebasan (DK) dengan ketentuan numerator : jumlah variabel -1 atau $4-1=3$, dan jumlah sampel dikurang 4 atau $52-4=48$. Dengan ketentuan tersebut, diperoleh nilai $\mathrm{F}_{\text {tabel }}$ sebesar 2.80. Dengan kriteria pengujian hipotesis sebagai berikut :

Jika $F_{\text {hitung }}>F_{\text {tabel, }}$, maka hipotesis penelitian diterima.

Jika $\mathrm{F}_{\text {hitung }}<\mathrm{F}_{\text {tabel}}$, maka hipotesis penelitian ditolak.

Dari hasil perhitungan diperoleh nilai $\mathrm{F}_{\text {hitung }}>\mathrm{F}_{\text {tabel }}(30.044>2.80)$ dan nilai signifikasi $0.00<0.05$, sehingga hipotesis yang diajukan dalam penelitian ini diterima. Artinya variabel kematangan guru, lingkungan kerja dan

Tabel 10. Model summary ${ }^{\mathrm{b}}$ pengaruh kematangan guru, lingkungan kerja dan kepemimpinan kepala madrasah terhadap kinerja

\begin{tabular}{|l|c|r|r|r|}
\hline Model & $R$ & $R$ Square & $\begin{array}{c}\text { Adjusted } R \\
\text { Square }\end{array}$ & $\begin{array}{c}\text { Std. Error of the } \\
\text { Estimate }\end{array}$ \\
\hline 1 & $.808^{\mathrm{a}}$ & .653 & .631 & 1.85644 \\
\hline
\end{tabular}

Dependent Variable : Kinerja

Sumber : Hasil pengolahan data, 2020

Besarnya Tabel 10 diatas diperoleh nilai Adjusted Rsquare $\left(\mathrm{r}^{2}\right)$ sebesar 0.631. Nilai tersebut mempunyai maksud bahwa pengaruh variabel kematangan guru, lingkungan kerja dan kepemimpinan kepala madrasah terhadap kinerja guru di Madrasah Aliyah Negeri kepemimpinan kepala madrasah secara simultan berpengaruh positif dan signifikan terhadap kinerja guru di Madrasah Aliyah Negeri Kabupaten Batu Bara. Dengan demikian model regresi ini sudah layak dan benar dan dapat disimpulkan bahwa variabel kematangan guru, lingkungan kerja dan kepemimpinan kepala madrasah berpengaruh terhadap kinerja guru di Madrasah Aliyah Negeri Kabupaten Batu Bara.

\subsection{Uji Determinan}

Uji determinan adalah untuk mengetahui seberapa besar pengaruh variabel kematangan guru, lingkungan kerja dan kepemimpinan kepala madrasah terhadap kinerja guru di Madrasah Aliyah Negeri Kabupaten Batu Bara, dan dapat dilihat dari model summary, khususnya nilai Adjusted Rsquare.

Kabupaten Batu Bara sebesar 63.10\%, sedangkan sisanya sebesar $36.90 \%$ dipengaruhi oleh faktor-faktor lain yang tidak diteliti. Dengan kata lain variabel kinerja guru di Madrasah Aliyah Negeri Kabupaten Batu Bara dapat diterangkan oleh variabel kematangan 
guru, lingkungan kerja dan kepemimpinan kepala madrasah sebesar $63.10 \%$, sedangkan sisanya sebesar $36.90 \%$ disebabkan oleh variabel-variabel lain yang tidak diteliti.

\section{Kesimpulan}

Berdasarkan pada pembahasan pada bab sebelumnya, maka dapat ditarik kesimpulan dari penelitian ini sebagai berikut :

1) Variabel kematangan guru secara partial berpengaruh positif dan signifikan terhadap kinerja guru di Madrasah Aliyah Negeri Kabupaten Batu Bara.

2) Variabel lingkungan kerja secara partial berpengaruh positif dan signifikan terhadap kinerja guru di Madrasah Aliyah Negeri Kabupaten Batu Bara.

3) Variabel kepemimpinan kepala madrasah secara partial berpengaruh positif dan signifikan terhadap kinerja guru di Madrasah Aliyah Negeri Kabupaten Batu Bara.

4) Variabel kematangan guru, lingkungan kerja dan kepemimpinan kepala madrasah secara simultan berpengaruh positif dan signifikan terhadap kinerja guru di Madrasah Aliyah Negeri Kabupaten Batu Bara.

\section{DAFTAR PUSTAKA}

Ali Imron (2013), Proses Manajemen Tingkat Satuan Pendidikan, Jakarta:Bumi Aksara

Arikunto, Suharsismi. (2002). Prosedur Penelitian Suatu Pendekatan Praktek. Jakarta: Rineka Cipta.

Colquitt, J. A., LePine, J. A., and Wesson., (2014) Organizational Behavior: Improving Performance and Commitment in the Workplace, New York, McGraw Hill, pp. 37

Cross, T.M dan Lynch. R.R. (2002). Peniliaian dan Evaluasi Kinerja: Konsep dan Praktik. Jakarta. Penerbit Ghalia Indonesia

Dessler, Gary. (2012). Manajemen Sumber Daya Manusia (Jilid I). Jakarta : Indeks.

E. Mulyasa (2011), Manajemen dan Kepemimpinan Kepala Sekolah, Jakarta: Bumi Aksara,

Fatah Syukur (2010), Manajemen Pendidikan Berbasis Pada Madrasah, (Semarang: Pustaka

Gibson, James L., Ivancevich, John M., Donnely, James H., and Konopaske (2014) Organizations: Behavior, Structure, Processes,New York, McGraw Hill
Goleman, D. (2014). Emotional Entellegent. PT. Gramedia Pustaka Utama, Jakarta

Hasibuan, Malayu S. P. (2013). Manajemen Sumber Daya Manusia. Edisi Revisi Jakarta: PT. Bumi Aksara.

M. Daryanto (2010), Administrasi Pendidikan, Jakarta: Rineka Cipta

Mangkunegara, Anwar, Prabu. (2014). Evaluasi Kinerja SDM, Cetakan 4, Bandung : Refika Aditama

Mangkuprawira, Sjafri. (2016). Manajemen Sumber Daya Manusia Strategik. Cetakan ketiga, Penerbit Ghalia Indonesia

Murphy, S. E., and Pirozzolo, F. J., (2002) Multi Journal ple Intelligences and Leadership, New Jersey, Lawrence Erlbaum

Ridwan. (2012). Skala Pengukuran VariabelVariabel Bandung : Alfabeta

Robbins S.P \& Judge,T.A. 2012. Perilaku Organisasi. Buku 1 Edisi 12. Terjemahan Diana Angelica. Penerbit Salemba Empat. Jakarta.

Robbins, Stephen P. (2006). Perilaku Organisasi. Edisi kesepuluh. Jakarta: Indeks Kelompok Gramedia.

Rush, Michael dan Althoff, Phillip. (2014). Pengantar Sosiologi Politik. Jakarta: PT. Raja Grafindo Persada.

Samsudin, Sadili. (2014). Manajemen Sumber Daya Manusia. Bandung: CV. Pustaka Setia.

Sedarmayanti. (2016). Good Governance (Kepemerintahan Yang Baik), Bandung : Mandar Maju

Sekaran, U., dan Bougie (2010), Research Methods for Busines. A Skill Building Approach. Fifth Edition. A John Wiley and Sons, Ltd, Publication.

Siagian, Sondang. (2013). Manajemen Sumber Daya Manusia (cetakan 15). Jakarta: Bumi Aksara

Sugiyono. (2014). Metode Penelitian Kuantitatif dan Kualitatif dan R \& D. Bandung : Alfabeta

Suryana Sumantri (2013). Perilaku Organisasi. Bandung: Universitas Padjadjaran

Sutrisno, Edy (2014). Manajemen Sumber Daya Manusia, Kencana Prenada Media Group Jakarta

Yukl, G. (2012). Kepemimpinan Dalam Organisasi. Edisi Indonesia (kelima). Cetakan kedua. Penerbit PT Indeks, Jakarta. 